\title{
Resource specialisation among suspension-feeding invertebrates on rock walls in Fiordland, New Zealand, is driven by water column structure and feeding mode
}

\author{
Stephen Wing*, Lucy Jack \\ Department of Marine Science, University of Otago, 310 Castle Street, Dunedin 9054, New Zealand
}

\begin{abstract}
Sessile suspension feeders are an important component of benthic-pelagic coupling on subtidal rocky reefs. We used stable isotope analysis to investigate intra-specific variation in trophic level and composition of basal organic matter sources (macroalgae and phytoplankton) supporting food webs used by sessile suspension feeders from rock wall sites throughout Fiordland in southwestern New Zealand. We characterised water column structure in terms of salinity and chlorophyll a from a 12 yr time series of CTD casts at 25 sites. During 2006 and 2010, at these same 25 sites, we measured the depth distribution of 8 common sessile suspensionfeeding invertebrates that use a broad range of feeding modes. In order to resolve variability in the use of basal organic matter sources in the food webs supporting these species, we measured $\delta^{13} \mathrm{C}$ and $\delta^{15} \mathrm{~N}$ of the 8 suspension-feeding species at 11 core sites. Using a mass balance approach, we assessed intra-specific variability in the composition of basal organic matter as well as the trophic level of each species. These data demonstrate distinct patterns of resource specialisation among species linked to depth distribution and to intra-specific variation in food web position. Our results indicate that species composition and depth distribution of benthic suspension feeders have important influences on benthic-pelagic coupling at the regional scale (100 to $300 \mathrm{~km})$.
\end{abstract}

KEY WORDS: Food web · Suspension feeding · Fiordland - Benthic-pelagic coupling $\cdot$ Diversity · Organic matter $\cdot$ Subtidal $\cdot$ Niche breadth

\section{INTRODUCTION}

Sessile suspension feeders are a ubiquitous component of subtidal rocky reefs and dominate the available space in many systems. On temperate reefs, suspension feeders form an important component of the benthic food web and are a key link between the suspended particulate organic matter (SPOM) pool and the benthos (Duggins et al. 1989, Gili \& Coma 1998). While suspension feeders as a group are often considered to be opportunists (Coma et al. 2001), the coexistence of a diverse array of species or functional groups at similar trophic levels has also raised questions about partitioning of resources and occupancy of different ecological niches in space and time. How does niche breadth vary among species of suspension feeders with different feeding modes and depth distributions?

Along rocky shores, observations of large inputs of kelp-derived organic matter to suspension-feeding communities has highlighted the contribution of macroalgae, in addition to phytoplankton, to the SPOM pool (Bustamante \& Branch 1996, Duggins \& Eckman 1997, Salomon et al. 2008). In these systems, bivalve molluscs display a large degree of intraspecific variation in resource use, ranging from phytoplankton-based to kelp-based organic matter and spanning several trophic levels (Fredriksen 2003, Hill et al. 2006, Nilsen et al. 2008). Such intraspecific variation in resource use has been widely 
observed in aquatic systems, as demonstrated by unexpected variance in isotopic signatures $\left(\delta^{15} \mathrm{~N}\right.$ and $\delta^{13} \mathrm{C}$ ) among individuals (e.g. Fry et al. 1999, Bolnick et al. 2003). These patterns likely reflect differences in the proportion of basal organic matter sources supplying food webs, as well as intra-specific variability in diet. In this context, analysis of $\delta^{15} \mathrm{~N}$ and $\delta^{13} \mathrm{C}$ provides a useful tool for quantifying differences in niche breadth among a diverse community of suspension-feeding invertebrates.

For sessile organisms, the inability to disperse as adults has been concomitant with adaptive strategies for coexistence in the face of large variations in availability of resources and environmental conditions. As a consequence, sessile suspension feeders display strong competition for space in order to access food resources, leading to diversification of form, life history strategies and mechanisms of particle capture (Riisgård \& Larsen 2001). In the shallow subtidal, depth distribution and diversity of suspension feeders has been linked to patterns in water column structure and flow, which both influence the quantity and composition of particulate organic matter (Witman et al. 1993, Smith 1998). These organisms play a pivotal role in the transfer of organic matter from the water column to the benthos (Gili \& Coma 1998). Therefore, a better understanding of mechanisms for partitioning of resources among species is key to understanding the effects of suspension feeder diversity on the supply of organic matter to benthic food webs.

Fiordland, in southwestern New Zealand, offers an ideal study system in which to examine patterns in niche breadth among suspension-feeding species. The network of fjords is characterised by strong gradients in surface salinity, wave exposure and irradiance along the axes of individual fjords (Stanton \& Pickard 1981, Wing et al. 2007). Rainfall in the region is prodigious, creating a persistent low salinity layer (LSL), which flows seaward from the inner fjord basins to become well-mixed from wind waves and oceanic swell in the outer fjord habitats. The dynamics of the LSL has a marked influence on the vertical zonation of sessile suspension feeders within the region (Grange et al. 1981, Smith \& Witman 1999) and also influences the relative strength of consumer interactions (Witman \& Grange 1998, Wing \& Leichter 2011). Benthic and pelagic productivity, and consequently the supply of benthic and pelagic sources of organic matter to the benthic food web, vary strongly along the axis of each fjord (Goebel et al. 2005, Wing et al. 2007, 2008). There are also large fluxes of terrestrial matter into the inner fjord habitats that enter the food web through benthic recycl- ing of organic matter by chemoautotrophs (McLeod \& Wing 2007). The result is a system with replicate gradients in the composition of basal organic matter that provides opportunities to make multiple comparisons of niche breadth among species.

We examine the vertical distribution of 8 common suspension-feeding invertebrates, representing a broad range of feeding strategies, relative to water column structure on rock walls in the New Zealand fjords. We use stable isotope analysis to investigate intra-specific variation in trophic level and in the composition of basal organic matter supporting food webs among species (hereafter collectively referred to as food web position). We then employ a multivariate statistical framework to test for species overlap in food web position based on these 2 metrics as a proxy for organic matter use. Using this approach, we are able to quantify intra- and inter-specific variation in resource use within the suspension-feeding community. These data and analyses provide an important test of the link between patterns of diversity and resource use in suspension-feeding guilds and the flux of organic matter from the pelagic to the benthic food web. This is particularly important for predicting the consequences of changing environmental conditions on the food web dynamics of shallow subtidal ecosystems.

\section{MATERIALS AND METHODS}

\section{Study sites}

The study was conducted along the southwest coast of the South Island of New Zealand at 25 semisheltered outer fjord and inner fjord locations (Fig. 1). Environmental data were collected from a series of oceanographic surveys conducted at all sites in 1998, 1999, 2002, 2003, 2005, 2006 and 2010. We collected salinity and chlorophyll $a$ (chl $a$; by proxy with fluorescence) readings every $0.5 \mathrm{~s}$ from the surface to 50 $\mathrm{m}$ at each study site using a Seabird SBE 19 conductivity, temperature and depth profiler (CTD) with an attached Wetstar fluorometer. Data were post-processed to $0.5 \mathrm{~m}$ bins using standard Seabird processing algorithms for the pumped SBE 19. Distributions of salinity and chl a were calculated among surveys and across strata centred on $0,2.5,5,10,15$ and $20 \mathrm{~m}$.

\section{Abundance surveys}

Photoquadrat surveys were carried out during February 2006 and February 2010 using a housed digital 


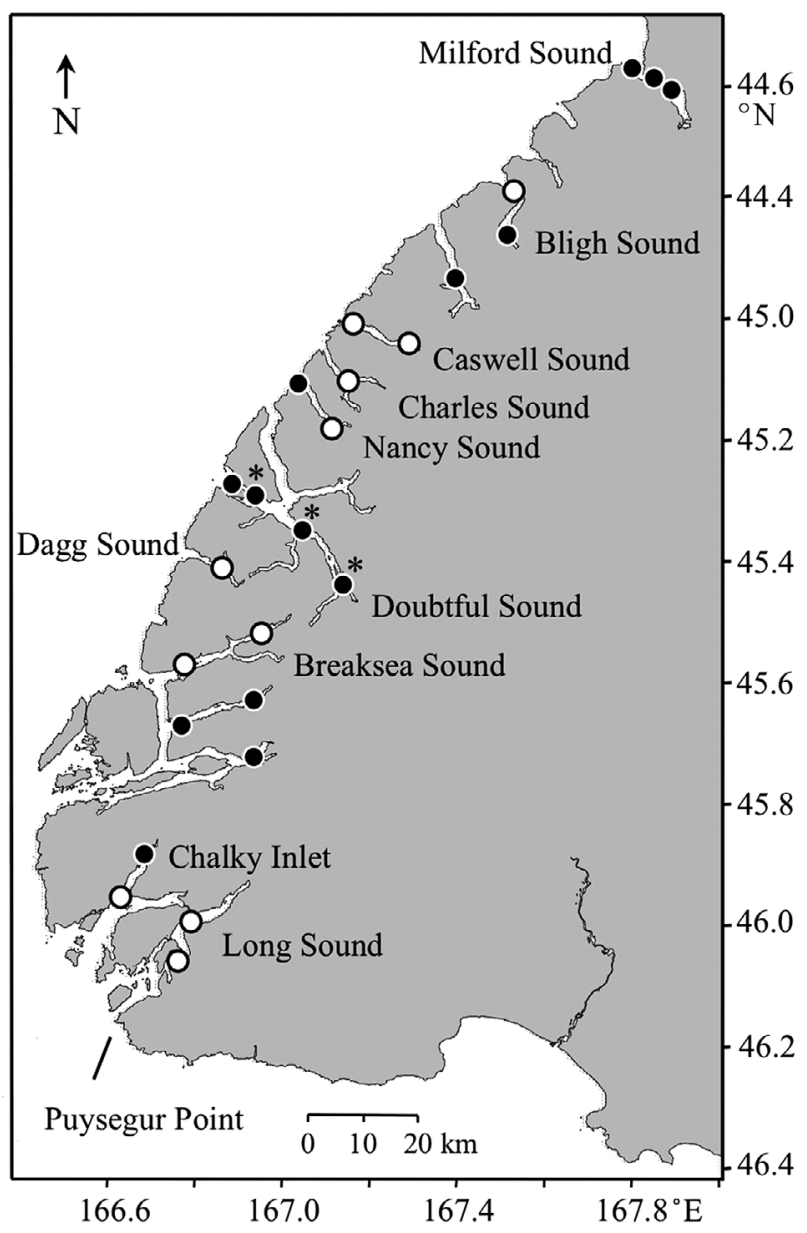

Fig. 1. Fiordland with location of study sites. O: core sites (11) where isotope data were collected for suspension-feeding invertebrates present. Suspended particulate organic matter (SPOM) samples were collected at 9 of these core sites, excluding those in Caswell Sound. @: additional sites (14) used in CTD and abundance surveys. *: sites (3) sampled during plankton bloom event

camera (Nikon D70 6.1 megapixel) mounted on a $0.17 \mathrm{~m}^{2}$ quadrat frame. Each survey was conducted by a SCUBA diver who randomly positioned 10 quadrats across a $100 \mathrm{~m}$ horizontal distance within each depth stratum (centred on 0, 2.5, 5, 10, 15 and $20 \mathrm{~m}$ ). The digital photos were post-processed from each stratum using the Nikon View 6.2.7 and Nikon Edit 6.2.7 programmes. The density of the mussels Mytilus galloprovincialis, Aulacomya maoriana and Perna canaliculus, the solitary ascidian Cnemidocarpa bicornuata, the tubeworm Neovermilia sphaeropomatus, and 2 brachiopods, Liothyrella neozelandea and Terebratella sanguinea, were quantified at each site per depth stratum.

Stratified band transect surveys were carried out at each site in February 2006 and February 2010 with replicate $50 \times 5 \mathrm{~m}$ band transects centred at 5, 10, 15, $20 \mathrm{~m}$ strata. Black coral (Antipathes fiordensis) colonies were enumerated and the average density by stratum was calculated among years for each site. No black coral colonies were observed at depths $<5 \mathrm{~m}$ in these surveys.

\section{Tissue samples of suspension feeders}

In November 2005 and February 2006, a depthstratified series of samples $(5,10,15,20 \mathrm{~m})$, with a target sample size of 5 individuals from each depth stratum, was collected at 11 core sites for each of the study species present at those sites and depths (Fig. 1). Samples of abductor muscle tissue were collected from each mussel species (Mytilus galloprovincialis, Aulacomya maoriana, Perna canaliculus), samples of smooth muscle tissue from the lophophore were collected from each brachiopod species (Liothyrella neozelandea, Terebratella sanguinea) and samples of smooth body wall muscle tissue were collected from the tubeworm Neovermilia sphaeropomatus and the solitary ascidian Cnemidocarpa bicornuata. Tissue of the black coral Antipathes fiordensis was removed from the skeleton from small samples collected from the tips of branches from each colony.

\section{$\delta^{13} \mathrm{C}$ and $\delta^{15} \mathrm{~N}$ of organic matter source pools}

Particulates. Samples of SPOM (n = 15 per site, total $\mathrm{n}=165$ ) were obtained from a depth-stratified $(1,5,10,15 \mathrm{~m})$ series of 51 Niskin bottle samples collected at 9 study sites in November 2003 and November 2004 (Fig. 1). Care was taken to collect samples within $10 \mathrm{~m}$ of the rock wall at each study site. Samples were filtered on pre-combusted Whatman GF/F filters and stored at $-20^{\circ} \mathrm{C}$. Filters were dried at $60^{\circ} \mathrm{C}$ and packed in individual tin capsules. Analysis was carried out for $\delta^{13} \mathrm{C}$ and $\delta^{15} \mathrm{~N}$. We used analysis of variance to test for differences in $\delta^{13} \mathrm{C}$ and $\delta^{15} \mathrm{~N}$ with 'site' (random) and 'depth' (fixed).

Plankton bloom event. In addition, SPOM samples were collected in December 2005 from inner, mid and outer fjord sites in Doubtful Sound during a phytoplankton bloom, size fractioned ( 0.7 to 20,20 to 200 and $>200 \mu \mathrm{m}$ ) and analysed for $\delta^{13} \mathrm{C}$ and $\delta^{15} \mathrm{~N}$. Samples were inspected under a compound microscope for abundance of phytoplankton. As spatial variation in $\delta^{15} \mathrm{~N}$ and $\delta^{13} \mathrm{C}$ of SPOM samples is generally low in this system, the stable isotopic signature of phyto- 
plankton was approximated by sampling SPOM during this phytoplankton bloom event (Wing et al. 2008).

Macroalgae. Ecophysiology of the dominant stipitate kelp Ecklonia radiata varies along the fjord axis relative to topographic shading and wave exposure (Wing et al. 2007), and spatial patterns in $\delta^{15} \mathrm{~N}$ and $\delta^{13} \mathrm{C}$ in the dominant fresh water algae Ulva pertusa vary with nutrient source pools and along physical gradients (Cornelisen et al. 2007). Abundance estimates of macroalgae from the LSL $(\mathrm{n}=228)$ and of $E$. radiata $(\mathrm{n}=260)$ were collected from a series of 5 sites along the axis of Doubtful Sound using stratified random quadrats $\left(0.1 \mathrm{~m}^{2}\right.$ for LSL, $2 \mathrm{~m}^{2}$ for E. radiata $)$. Samples of Ulva sp., Gracilaria sp., Gymnogongrus sp., and Cladophora sp. $(\mathrm{n}=29)$ were collected from the LSL where they comprise $>90 \%$ of the available macroalgal biomass (K. Clark unpubl. data), and samples of E. radiata $(\mathrm{n}=14)$ were collected from depths of 10 to $15 \mathrm{~m}$ where the kelp is the most common large brown alga (Miller et al. 2006). Site-specific $\delta^{13} \mathrm{C}$ and $\delta^{15} \mathrm{~N}$ for each species were weighted by biomass at each site and then averaged among sites to obtain an aggregate isotopic signature for 'macroalgae'.

Stable isotope analysis. Analyses were performed in the Department of Chemistry, University of Otago. Samples of primary producers and macroinvertebrates were dried at $60^{\circ} \mathrm{C}$, ground with a mortar and pestle, then weighed into individual tin capsules. Samples were analysed for $\delta^{15} \mathrm{~N}$ and $\delta^{13} \mathrm{C}$ on a Europa 20-20 update stable isotope mass spectrometer (Europa Scientific) interfaced to a Carlo Erba elemental analyzer (NA1500, Carlo Erba) in continuous flow mode (precision: $0.2 \%$ for $\delta^{13} \mathrm{C}, 0.3 \%$ for $\delta^{15} \mathrm{~N}$, where precision $=1 \mathrm{SD}$ of laboratory standards). Analysis was calibrated to EDTA laboratory standard reference (Elemental Microanalysis) and standardised against international standards (IAEACH- 6 for carbon, IAEAN1 and IAEAN2 for nitrogen). Results were expressed in the standard delta notation (e.g. Peterson \& Howarth 1987) where, for example, $\delta^{13} \mathrm{C}=$ $\left[\left(R_{\text {smpl }} / R_{\text {std }}\right)-1\right] \times 1000$, where $R_{\text {smpl }}={ }^{13} \mathrm{C} /{ }^{12} \mathrm{C}$ and $R_{\text {std }}$ $={ }^{13} \mathrm{C} /{ }^{12} \mathrm{C}$ of Pee Dee belemnite limestone.

Analysis of density patterns with depth. We used ANOVA (SAS JMP V7.0) to test for significant effects of site (random, 25 levels) and depth (fixed, 5 levels) on density of each species of suspension feeder. Data distributions were tested for normality and heterogeneity of variance among treatments prior to ANOVA. Where ANOVA indicated significant effects, Tukey's post-hoc pair-wise comparisons were conducted among depths.

Mass balance analysis. We used a 2 step iterative procedure to measure individual estimates of trophic level and the proportion of organic matter sources (macroalgae and phytoplankton) in food webs supporting individuals (sensu Jack \& Wing 2011). A 2source mass balance model using $\delta^{13} \mathrm{C}$ after Phillips \& Gregg (2001) was used to calculate the relative contribution of macroalgae and phytoplankton to the diet of each individual for each species. We used the results of this model to estimate the corresponding $\delta^{15} \mathrm{~N}_{\text {base }}$ of the mixture of basal organic matter sources supporting each individual. From this $\delta^{15} \mathrm{~N}_{\text {base }}$ value, we could then calculate trophic level for each individual, based on Post (2002). Trophic level was defined as: $\left(\Delta^{15} N_{\text {consumer }}-\Delta{ }^{15} N_{\text {base }} / \varnothing_{n}\right)+1$, where $\varnothing_{n}$ is the trophic discrimination factor per trophic level, so that level 1 was primary productivity. We used the average trophic discrimination factors $\Delta^{15} \mathrm{~N}$ of $+2.3 \%$ (SE 0.28 ) and $\Delta^{13} \mathrm{C}$ of $+0.4 \%$ (SE 0.17 ) for aquatic environments after McCutchan et al. (2003) for each enrichment step. The resulting estimate of trophic level was then iterated back into the mass balance model until a stable solution was obtained for both the mixture of organic matter sources and trophic level for each individual sampled.

Multivariate analyses were conducted using PERMANOVA+ for Primer V6.0 (Anderson et al. 2008) on standardised data to test for differences in food web position (trophic level and composition of basal organic matter sources) among 'species' (fixed, 8 levels) and 'sites' (random). We tested for inter-specific differences in dispersion in food web position (niche breadth) using a distance-based test for homogeneity of multivariate dispersions (PERMDisp) and visualised the multivariate spread of individuals using a principal coordinate analysis ( $\mathrm{PCO}$ ).

In order to test the sensitivity of our results to variability in trophic discrimination factors $\left(\Delta^{13} \mathrm{C}\right.$ and $\left.\Delta^{15} \mathrm{~N}\right)$, we ran iterations of the mass balance model with $\pm 1 \mathrm{SE}$ of $\Delta^{13} \mathrm{C}$ and $\Delta^{15} \mathrm{~N}$ after McCutchan et al. (2003). We then retested our data using PERMANOVA for significant deviations from the average case.

\section{RESULTS}

\section{Oceanographic surveys}

Average salinity by depth at the 25 study sites across years indicated a distinct surface LSL in Fiordland, consistent with the LSL described in previous studies (Stanton \& Pickard 1981) (Fig. 2a). The water column structure indicated a 2 layered system with the LSL occupying the surface above $5 \mathrm{~m}$ and the consistent marine layer occupying depths $5 \mathrm{~m}$ and 

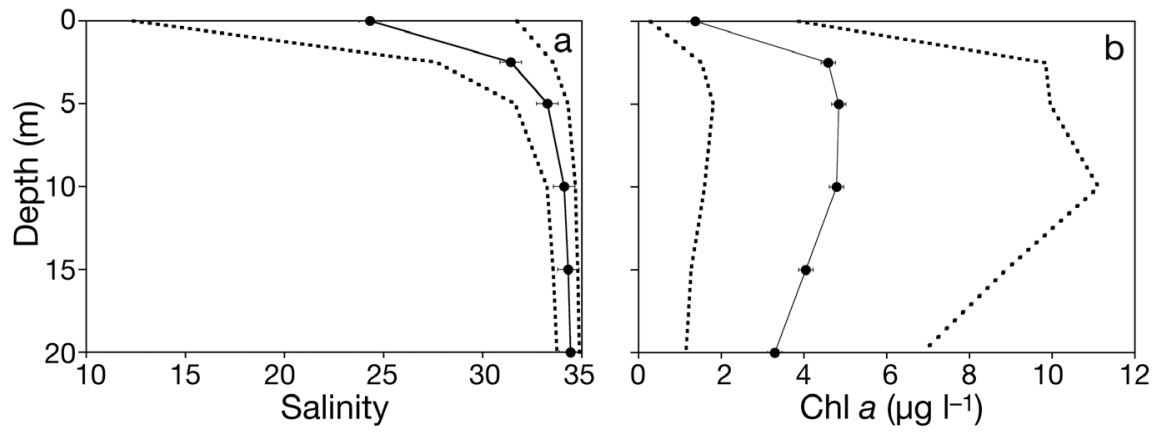

Fig. 2. (a) Salinity and (b) chl a ( $\mu \mathrm{g}$ $\mathrm{l}^{-1}$ ) among the 25 study sites from CTD casts collected in 1998, 1999, 2002, 2003, 2005, 2006 and 2010. Means $\pm 1 \mathrm{SE}$ among years; dashed lines indicate average minimum and maximum among sites below. A peak in average chl a was observed in the region immediately below the LSL at 5 to $10 \mathrm{~m}$ depth (Fig. 2b).

\section{Abundance surveys}

Abundance patterns of the 8 species were separable into 2 groups. The first group was made up of 3 species of euryhaline mussels that were confined to the low salinity layer. Average density by depth among sites for Mytilus galloprovincialis indicated highest abundance in the $0 \mathrm{~m}$ depth stratum (Fig. 3a). Average density of Aulacomya maoriana was distributed between 0 and $2.5 \mathrm{~m}$ depth strata (Fig. 3b), whilst the peak density of Perna canaliculus was highest in the $5 \mathrm{~m}$ depth stratum (Fig. 3c)
A second group of species was made up of stenohaline invertebrates that were distributed in the marine layer below the LSL from $5 \mathrm{~m}$ to $20 \mathrm{~m}$ depth. Within this marine layer group, average density among sites for the ascidian Cnemidocarpa bicornuata was highest within the $5 \mathrm{~m}$ depth stratum and decreased slightly with depth (Fig. 3d). Density of the tubeworm Neovermilia sphaeropomatus peaked below the $5 \mathrm{~m}$ stratum and was relatively consistent until a decline at the 20 m stratum (Fig. 3e). Density of the brachiopod Terebratella sanguinea peaked in the $10 \mathrm{~m}$ stratum and was consistently high at deeper strata (Fig. 3f), while average density of the gregarious brachiopod Liothyrella neozelandea increased below $10 \mathrm{~m}$ to a strong peak at $20 \mathrm{~m}$ (Fig. 3g). A similar pattern was observed for the black coral Antipathes fiordensis with a strong peak in density at $20 \mathrm{~m}$ (Fig. 3h).
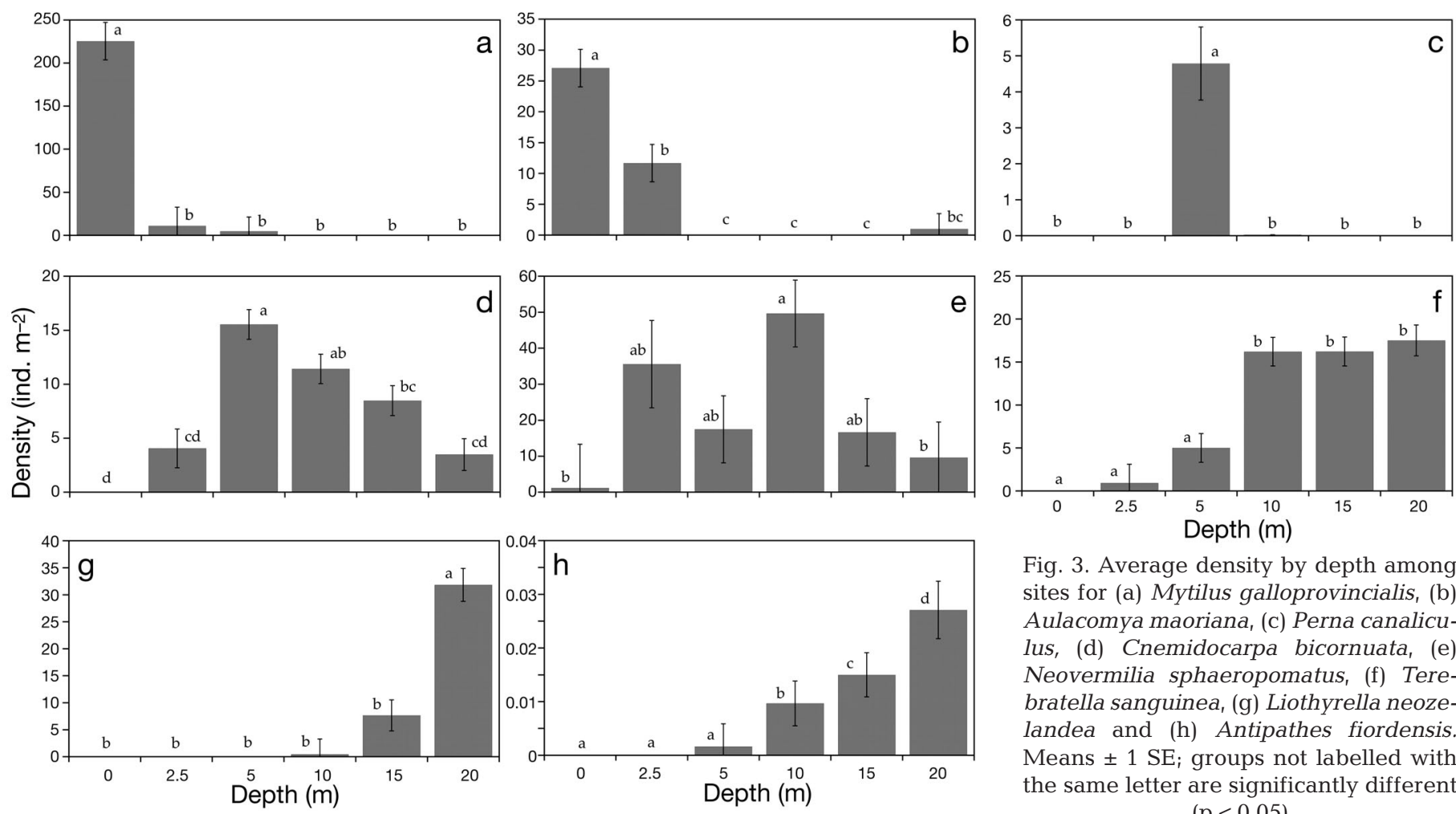

Fig. 3. Average density by depth among sites for (a) Mytilus galloprovincialis, (b) Aulacomya maoriana, (c) Perna canaliculus, (d) Cnemidocarpa bicornuata, (e) Neovermilia sphaeropomatus, (f) Terebratella sanguinea, (g) Liothyrella neozelandea and (h) Antipathes fiordensis. Means $\pm 1 \mathrm{SE}$; groups not labelled with the same letter are significantly different $(\mathrm{p}<0.05)$ 


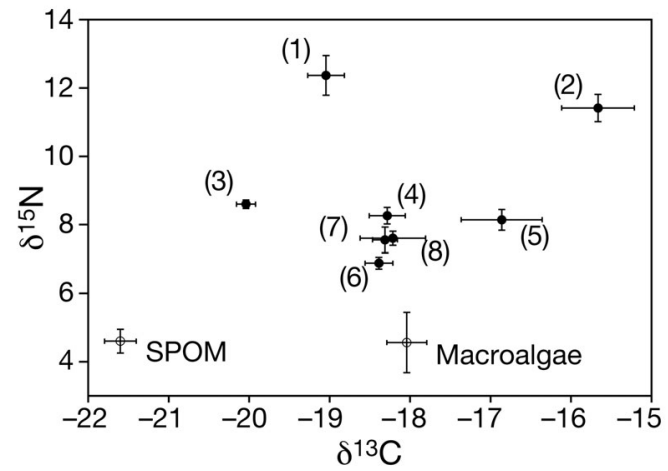

Fig. 4. $\delta^{13} \mathrm{C}$ and $\delta^{15} \mathrm{~N}$ for basal organic matter sources: macroalgae and suspended particulate organic matter (SPOM) and consumers: (1) Antipathes fiordensis, (2) Liothyrella neozelandea, (3) Cnemidocarpa bicornuata, (4) Neovermilia sphaeropomatus, (5) Terebratella sanguinea, (6) Perna canaliculus, (7) Mytilus galloprovincialis and (8) Aulacomya maoriana. Means $\pm 1 \mathrm{SE}$

\section{$\delta^{13} \mathrm{C}$ and $\delta^{15} \mathrm{~N}$ of organic matter source pools}

Particulates. $\delta^{13} \mathrm{C}$ and $\delta^{15} \mathrm{~N}$ of SPOM samples were not significantly different among sites or depths for the Fiordland wide survey $\left(\delta^{13} \mathrm{C}\right.$ : 'site' $F_{8}=2.23, \mathrm{p}=$ 0.06 ; 'depth' $F_{3}=2.34, \mathrm{p}=0.10 ; \delta^{15} \mathrm{~N}$ : 'site' $F_{8}=0.79$, $\mathrm{p}=0.61$; 'depth' $F_{3}=0.89, \mathrm{p}=0.21$ ).

Plankton bloom event. Visual inspection of SPOM samples taken during the plankton bloom event revealed large concentrations of diatoms (primarily Skeletonema costatum) and dinoflagellates making up a majority of the particulate organic matter in the 20 to $200 \mu \mathrm{m}$ size fraction. We therefore used $\delta^{13} \mathrm{C}$ $(-21.6 \pm 0.197$, mean $\pm \mathrm{SE})$ and $\delta^{15} \mathrm{~N}(4.6 \pm 0.348)$ of the 20 to $200 \mu \mathrm{m}$ size fraction to characterise organic matter from phytoplankton (Fig. 4).

Stable isotope signatures of consumers and mass balance analysis. $\delta^{13} \mathrm{C}$ and $\delta^{15} \mathrm{~N}$ differed among species with the largest differences observed among the more deeply distributed species and relatively similar isotopic signatures observed among the 3 mussels (Fig. 4). No evidence for use of organic matter sources depleted in ${ }^{13} \mathrm{C}$, such as terrestrial organic matter or chemosynthetically derived organic matter, was observed in these species (e.g. McLeod et al. 2010).

Individual-based estimates of food web position revealed distinct patterns in variability among species, and among groups of species distributed within the LSL and within the underlying marine layer (PERMANOVA; pseudo- $F=60.23, \mathrm{df}=7,15, \mathrm{p}=$ 0.001) (Fig. 5). Pairwise tests among species for trophic level and proportion of organic matter from macroalgae reveal significant differences among species (Fig. 5). These tests were robust to deviations
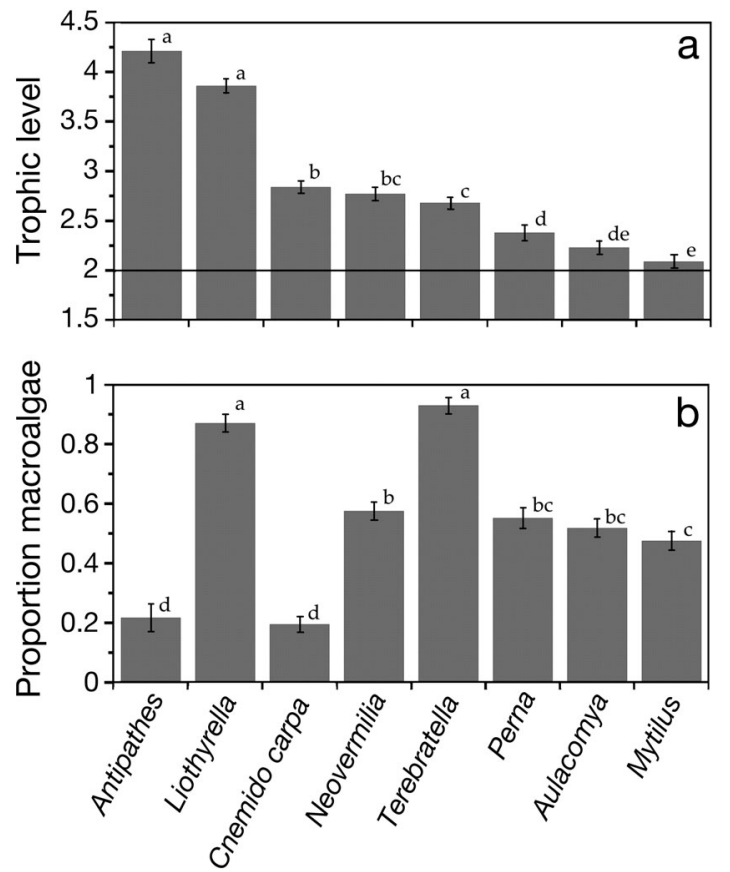

Fig. 5. (a) Estimates of trophic level by species. Primary production is indicated by 1 . Horizontal line indicates trophic level of primary consumers. (b) Estimates of proportion of organic matter originating from macroalgae. Means \pm 1 SE. Species not labelled with the same letter are significantly different

of $\pm 1 \mathrm{SE}$ in $\Delta^{13} \mathrm{C}$ and $\Delta^{15} \mathrm{~N}$ carried out in our sensitivity analysis. In the LSL, the food web position of the mussels Mytilus galloprovincialis, Aulacomya maoriana and Perna canaliculus were broadly overlapping (Fig. 6a), and mean food web position did not differ significantly among species (PERMANOVA; pseudo$F=1.861, \mathrm{df}=2,10, \mathrm{p}=0.16)$. A distance-based test for homogeneity of multivariate dispersion could not detect significant inter-individual variability in diet among species (PERMDisp; pseudo- $F=0.50$, df $=$ $2,99, \mathrm{p}=0.66)$.

Within the underlying marine layer, species fell into 2 distinct trophic groups. The solitary ascidian Cnemidocarpa bicornuata, the tubeworm Neovermilia sphaeropomatus and the brachiopod Terebratella sanguinea (all distributed with highest densities between 5 and $15 \mathrm{~m}$ ), fed at average trophic levels of 2.68 to 2.84 , which indicates primary consumption of SPOM and some zooplanktivory (Fig. 5a). The gregarious brachiopod Liothyrella neozelandea and black coral Antipathes fiordensis fed at average trophic levels of 3.86 and 4.21 respectively, indicative of secondary consumption, or exclusive zooplanktivory (Figs. 4,5a).

The 3 primary consumers differed significantly in food web position among species (PERMANOVA; 


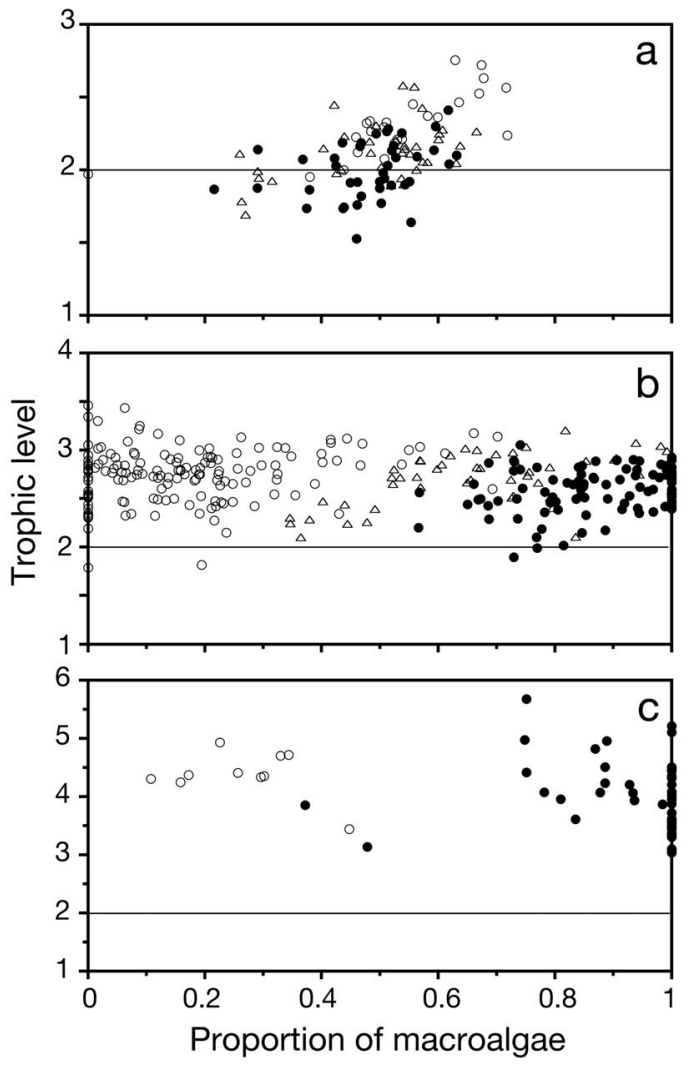

Fig. 6. Individual trophic level and fraction of macroalgae making up basal organic matter source for (a) Mytilus galloprovincialis $(\bullet)$, Aulacomya maoriana $(\Delta)$, Perna canaliculus (০); (b) Cnemidocarpa bicornuata (০), Terebratella san-

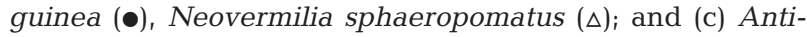
pathes fiordensis (০), Liothyrella neozelandea (•) Horizontal line indicates trophic level of primary consumers

pseudo- $F=29.92, \mathrm{df}=2,10, \mathrm{p}=0.0001$ ). The ascidian Cnemidocarpa bicornuata displayed a high use of organic matter from phytoplankton, the brachiopod Terebratella sanguinea showed a high use of macroalgae-derived organic matter, while the tubeworm Neovermilia sphaeropomatus displayed large variability in organic matter sources among individuals (Fig. 6b). A pair-wise PERMANOVA on food web position among species revealed significant differences between $C$. bicornuata, and $N$. sphaeropomatus $(t=3.38, \mathrm{p}=0.004), C$. bicornuata and $T$. sanguinea $(t=6.43, \mathrm{p}=0.0001)$ and $N$. sphaeropomatus and $T$. sanguinea $(t=3.11, \mathrm{p}=0.008)$. A PERMDisp revealed no significant differences in individuallevel dispersion of food web position among species (PERMDisp; pseudo- $F=10.035, \mathrm{df}=2,295, \mathrm{p}=0.16$ ).

The 2 secondary consumers Liothyrella neozelandea and Antipathes fiordensis differed significantly in food web position (PERMANOVA; pseudo- $F=$ $100.85, \mathrm{df}=1,7, \mathrm{p}=0.002$ ) but not in dietary disper- sion (PERMDisp; pseudo- $F=2.93, \mathrm{df}=1,56, \mathrm{p}=$ 0.102). Black coral A. fiordensis used a larger fraction of organic matter originating from phytoplankton while the gregarious brachiopod $L$. neozelandea used a higher fraction of organic matter originating from macroalgae (Fig. 6c).

\section{DISCUSSION}

The data and analyses presented here demonstrate important influences of intra-specific variation in trophic level and composition of basal organic matter on the food web structure of sessile suspensionfeeding communities. In the present example, strong and persistent water column structure coincided with a dramatic division in vertical distribution among 8 common suspension-feeding species. We observed that along the near vertical rock wall habitats, the low salinity layer hosted dense aggregations of relatively euryhaline mussels, while the underlying seawater layer supported a taxonomically and functionally diverse community of suspension feeders, consistent with previous studies of the system (Witman \& Grange 1998, Smith \& Witman 1999, Rutger \& Wing 2006, Wing \& Leichter 2011). This provided a basis for comparison of both food web position and niche breadth among species distributed within each water mass, and between species from the LSL and underlying marine layer.

Our analysis of resource specialisation, as indicated by intra-specific variation in food web position, reveals that the 3 co-occurring mussel species in the LSL largely overlapped in resource use. This is consistent with observations of the relatively opportunistic use of SPOM by mussels distributed along environmental gradients (e.g. Bustamante et al. 1995, Hill et al. 2006). However, among the functionally diverse group of suspension feeders in the underlying marine layer, we found a greater range of variability among species in terms of food web position. Estimates of trophic level for the 2 most deeply distributed species, the brachiopod Liothyrella neozelandea and the large black coral Antipathes fiordensis, indicated exclusive zooplanktivory. Further, estimates of the composition of organic matter sources indicated that $A$. fiordensis was supported largely by a food web based on phytoplankton. This is consistent with studies of feeding in black corals, which capture passing zooplankton from the water column (Stewart 1998). Colonies reach 1 to $3 \mathrm{~m}$ out from rock walls in the Fiordland region and are thus able to extend through the benthic boundary layer along 
rock wall habitats into mainstream flow, providing a strong link with the pelagic community. In distinct contrast, the gregarious brachiopod L. neozelandea relies on weak feeding currents and its relatively small size and restricted distribution (confined to rocky overhangs) places it deep within the benthic boundary layer and in close proximity with the mixed algal turf and invertebrate community. Food web position of this species indicates a strong reliance on prey species supported by macroalgae. This pattern is consistent with the habit of $L$. neozelandea and indicates very weak coupling with pelagic sources of organic matter for this species.

Within the group of stenohaline primary consumers (the ascidian Cnemidocarpa bicornuata, the tubeworm Neovermilia sphaeropomatus and the brachiopod Terebratella sanguinea), intra-specific variation in diet is broad. However there are distinct patterns among species. Estimates of the organic matter sources for the active suspension-feeding solitary ascidian $C$. bicornuata indicate a strong reliance on pelagic sources of organic matter. The peak abundance of this species at $5 \mathrm{~m}$ corresponds with the peak in chl a concentration, consistent with a phytoplankton-based diet. In contrast, the more deeply distributed brachiopod T. sanguinea relies more heavily on organic matter originating from macroalgae. This small species is found distributed across the rock walls in algal turf habitats, where they likely receive particulate organic matter derived from macroalgae. Estimates of diet for the tubeworm $N$. sphaeropomatus span the range of the other 2 stenohaline species, consistent with their scattered depth distribution across rock wall habitats. These data are indicative of a more opportunist use of organic matter ranging from pelagic to benthic sources.

Our observations of distinct patterns in food web position among species have important implications for understanding the roll of intra-specific variation in resource specialisation for suspension-feeding species and for the interaction of depth distribution, feeding mode and food web structure in this group. The species considered here represent a broad array of suspension-feeding modes, which indicate considerable scope for specialisation for different particle sizes and types in the water column, as well as different interactions of feeding currents with the benthic boundary layer and free stream flow adjacent to rock walls.

The 3 bivalve species use cirral trapping, in which strong water currents are driven by bands of cilia through interfilamentary canals within the gills. In all 3 species, strong feeding currents, confined depth distribution in the LSL and highly mixed water in the wave wash zone likely result in their using a mixture of organic matter from phytoplankton and macroalgae. In this system, organic matter originating from dense communities of shallow water macroalgae comprise an important component of diet, but there is also evidence for a strong link with pelagic productivity.

In contrast, the diversity of feeding modes observed in the underlying marine layer are associated with more specialised use of organic matter sources and a larger range of trophic levels. For example, brachiopods use ciliary upstream feeding to divert particles from the main water current and direct them to the upstream side of the feeding structure, the lophophore. Generally, weak feeding currents are associated with this type of particle capture and brachiopods are cryptically distributed within turf and encrusting invertebrates, often with significant epibont cover. Our observations of high use of macroalgae-derived organic matter in Terebratella sanguinea is consistent with this habit, which is closely tied to benthic productivity.

Ascidians employ mucus net sieving and a strong ciliary driven pump to capture particles drawn into the pharyngeal chamber through small openings, the stigmata. Strong feeding currents are associated with this mode of feeding and the solitary ascidian Cnemidocarpa bicornuata has a strong upright form with incurrent and excurrent siphons extending 10 to $12 \mathrm{~cm}$ from the rock wall that direct flow across the benthic boundary layer. Our data show that this feeding mode results in strong benthic-pelagic coupling where a large component of the basal organic matter fed upon originates from phytoplankton.

Suspension-feeding polychaetes such as Neovermilia sphaeropomatus use ciliary downstream particle collecting to redirect the course of particles entrained in the main flow into a food groove and into the control of lateral cilia on each feeding tentacle. As only weak feeding currents are associated with this feeding mode, particle capture is strongly influenced by the immediate flow environment. Similarly the black coral Antipathes fiordensis relies on direct interception of particles with feeding polyps, while the interaction of flow with the colonies tends to direct particles into a turbulent wake increasing chance of capture. Colonies of black coral are typically found on rocky ridges that extend out from the fjord walls and the colonies themselves extend 1 to $3 \mathrm{~m}$ out into the mainstream flow past these rock wall habitats.

The results presented here rely heavily on mass balance analysis of $\delta^{13} \mathrm{C}$ and $\delta^{15} \mathrm{~N}$ to estimate trophic 
levels and composition of organic matter sources used by each species. Mass balance estimates are subject to several caveats in their interpretation. First, spatial variation in $\delta^{13} \mathrm{C}$ and $\delta^{15} \mathrm{~N}$ of organic matter sources can cause large errors in mass balance estimates of organic matter composition as well as errors in estimates of trophic level if source pool variability is not constrained in the analysis. We accomplish this constraint by measuring large-scale variability in the SPOM pool and we observed no significant variability in $\delta^{13} \mathrm{C}$ and $\delta^{15} \mathrm{~N}$ among sites. Based on this result, we employed a mass balance analysis using averages of $\delta^{13} \mathrm{C}$ and $\delta^{15} \mathrm{~N}$ for phytoplankton and macroalgae source pools. These source pools were sampled along the axis of greatest environmental variability in the fjords to ensure representative values of $\delta^{13} \mathrm{C}$ and $\delta^{15} \mathrm{~N}$. We refined our estimate of the variability in the macroalgae source pool by computing an average of $\delta^{13} \mathrm{C}$ and $\delta^{15} \mathrm{~N}$ weighted to biomass of the most abundant species among 5 sites distributed along the primary environmental gradients in the system (Cornelisen et al. 2007).

Estimates of trophic level may be subject to significant sources of error from inter-specific differences in the trophic discrimination factors $\Delta^{13} \mathrm{C}$ and $\Delta^{15} \mathrm{~N}$ (Caut et al. 2009, Newsome et al. 2010). One approach to account for inter-specific variability in $\Delta^{13} \mathrm{C}$ and $\Delta^{15} \mathrm{~N}$ is to estimate specific values for each species in a food web. However, additional variability may be imposed on these estimates from metabolic differences among individuals that affect isotopic discrimination between diet and consumer (Hill \& McQuaid 2009). A second approach, and the one employed here, is to statistically test the sensitivity of results using the reported variability in $\Delta^{13} \mathrm{C}$ and $\Delta^{15} \mathrm{~N}$ (e.g. Jack \& Wing 2011). In our analysis, we varied $\Delta^{13} \mathrm{C}$ and $\Delta^{15} \mathrm{~N}$ by $\pm 1 \mathrm{SE}$ and reanalysed our data. In this case, we did not find deviations in results from those reported for the average case, indicating our results were relatively robust to the reported variance in $\Delta \Delta^{13} \mathrm{C}$ and $\Delta{ }^{15} \mathrm{~N}$.

The present study provides an important example of resource specialisation resulting in niche partitioning among suspension-feeding invertebrates. We observed dramatic variability in trophic level and in relative use of phytoplankton and macroalgaederived SPOM among co-occurring suspension feeders, indicating significant differences in food web position within this guild. In Fiordland, the persistent structure of the water column and near vertical rock walls provide an ideal study system for resolving these effects in nature. Much of the observed variability in food web position among species could be statistically explained by depth distribution and feeding mode, reflecting large differences in benthic-pelagic coupling among species. These patterns demonstrate that the flux of organic matter between benthic and pelagic systems is strongly influenced by functional diversity of suspension-feeding invertebrates in subtidal food webs.

Acknowledgements. We thank C. Cornelisen, R. McLeod, S. Rutger, H. Bowman, R. van Hale, N. Goebel and F. Smith for assistance with this work. Technical support was provided from the Departments of Marine Science and Chemistry at the University of Otago. Monetary support was provided by the Royal Society of New Zealand Marsden Fund to S.W. (UO-00213).

\section{LITERATURE CITED}

Anderson M, Gorley R, Clarke K (2008) PERMANOVA+ for PRIMER: guide to software and statistical methods. University of Auckland, Auckland

Bolnick DI, Svanbäck R, Fordyce JA, Yang LH, Davis JM, Hulsey CD, Forister ML (2003) The ecology of individuals: incidence and implications of individual specialization. Am Nat 161:1-28

Bustamante R, Branch G (1996) The dependence of intertidal consumers on kelp-derived organic matter on the west coast of South Africa. J Exp Mar Biol Ecol 196:1-28

Bustamante R, Branch G, Eekhout S, Robertson B and others (1995) Gradients in intertidal primary productivity around the coast of South Africa and their relationships with consumer biomass. Oecologia 102:189-201

Caut S, Angulo E, Courchamp F (2009) Variation in discrimination factors $\left(\Delta^{15} \mathrm{~N}\right.$ and $\left.\Delta^{13} \mathrm{C}\right)$ : the effect of diet isotopic values and applications for diet reconstruction. J Appl Ecol 46:443-453

> Coma R, Ribes M, Gili JM, Hughes R (2001) The ultimate opportunists: consumers of seston. Mar Ecol Prog Ser 219:305-308

> Cornelisen CD, Wing SR, Clark KL, Bowman MH, Frew RD, Hurd CL (2007) Patterns in $\delta^{13} \mathrm{C}$ and $\delta^{15} \mathrm{~N}$ signatures of Ulva pertusa: interaction between physical gradients and nutrient source pools. Limnol Oceanogr 52:820-832

> Duggins DO, Simenstad CA, Estes JA (1989) Magnification of secondary production by kelp detritus in coastal marine ecosystems. Science 245:170-173

> Duggins D, Eckman J (1997) Is kelp detritus a good food for suspension feeders? Effects of kelp species, age and secondary metabolites. Mar Biol 128:489-495

> Fredriksen S (2003) Food web studies in a Norwegian kelp forest based on stable isotope $\left(\delta^{13} \mathrm{C}\right.$ and $\left.\delta^{15} \mathrm{~N}\right)$ analysis. Mar Ecol Prog Ser 260:71-81

> Fry B, Mumford P, Tam F, Fox D, Warren G, Havens K, Steinman A (1999) Trophic position and individual feeding history of fish from Lake Okeechobee, Florida. Can J Fish Aquat Sci 56:590-600

> Gili JM, Coma R (1998) Benthic suspension feeders: their paramount role in littoral marine food webs. Trends Ecol Evol 13:316-321

Goebel N, Wing S, Boyd P (2005) A mechanism for onset of diatom blooms in a fjord with persistent salinity stratification. Estuar Coast Shelf Sci 64:546-560 
Grange K, Singleton R, Richardson J, Hill P, del Main W (1981) Shallow rock-wall biological associations of some southern fiords of New Zealand. NZ J Zool 8:209-227

Hill J, McQuaid C (2009) Effects of food quality on tissuespecific isotopic ratios in the mussel Perna perna. Hydrobiologia 635:81-94

> Hill J, McQuaid C, Kaehler S (2006) Biogeographic and nearshore-offshore trends in isotope ratios of intertidal mussels and their food sources around the coast of southern Africa. Mar Ecol Prog Ser 318:63-73

Jack L, Wing S (2011) Individual variability in trophic position and diet of a marine omnivore is linked to kelp bed habitat. Mar Ecol Prog Ser 443:129-139

McCutchan JH Jr., Lewis WM Jr., Kendall C, McGrath CC (2003) Variation in trophic shift for stable isotope ratios of carbon, nitrogen, and sulfur. Oikos 102:378-390

McLeod RJ, Wing SR (2007) Hagfish in the New Zealand fjords are supported by chemoautotrophy of forest carbon. Ecology 88:809-816

> McLeod R, Wing S, Skilton J (2010) High incidence of invertebrate-chemoautotrophic symbioses supports the macro-infaunal community in the New Zealand fjords. Limnol Oceanogr 55:2097-2106

Miller SM, Wing SR, Hurd CL (2006) Photoacclimation of Ecklonia radiata (Laminariales, Heterokontophyta) in Doubtful Sound, Fiordland, Southern New Zealand. Phycologia 45:44-52

> Newsome SD, Bentall GB, Tinker MT, Oftedal OT, Ralls K, Estes JA, Fogel ML (2010) Variation in $\delta^{13} \mathrm{C}$ and $\delta^{15} \mathrm{~N}$ diet-vibrissae trophic discrimination factors in a wild population of California sea otters. Ecol Appl 20: 1744-1752

Nilsen M, Pedersen T, Nilsen E, Fredriksen S (2008) Trophic studies in a high-latitude fjord ecosystem - a comparison of stable isotope analyses $\left(\delta^{13} \mathrm{C}\right.$ and $\left.\delta^{15} \mathrm{~N}\right)$ and trophic-level estimates from a mass balance model. Can J Fish Aquat Sci 65:2791-2806

> Peterson BJ, Howarth RW (1987) Sulfur, carbon, and nitrogen isotopes used to trace organic matter flow in the saltmarsh estuaries of Sapelo Island, Georgia. Limnol Oceanogr 32:1195-1213

Phillips D, Gregg J (2001) Uncertainty in source partitioning using stable isotopes. Oecologia 127:171-179

Post D (2002) Using stable isotopes to estimate trophic position: models, methods, and assumptions. Ecology 83:

Editorial responsibility: Antony Underwood,

Sydney, New South Wales, Australia
703-718

Riisgård H, Larsen P (2001) Ciliary filter feeding and biofluid mechanics - present understanding and unsolved problems. Limnol Oceanogr 46:882-891

Rutger S, Wing S (2006) Effects of freshwater input on shallow water infaunal communities in Doubtful Sound, New Zealand. Mar Ecol Prog Ser 314:35-47

Salomon AK, Shears NT, Langlois TJ, Babcock RC (2008) Cascading effects of fishing can alter carbon flow through a temperate coastal ecosystem. Ecol Appl 18: 1874-1887

Smith F (1998) Subtidal landscapes of a New Zealand fjord: patterns of species diversity, community structure and recruitment processes. PhD thesis, University of Otago, Dunedin

Smith F, Witman J (1999) Species diversity in subtidal landscapes: maintenance by physical processes and larval recruitment. Ecology 80:51-69

Stanton B, Pickard G (1981) Physical oceanography of the New Zealand fiords. NZOI Mem 88:3-37

Stewart B (1998) Can a snake star earn its keep? Feeding and cleaning behaviour in Astrobrachion constrictum (Farquhar) (Echinodermata: Ophiuroidea), a euryalid brittle-star living in association with the black coral, Antipathes fiordensis (Grange, 1990). J Exp Mar Biol Ecol 221:173-189

> Wing S, Leichter J (2011) Variation in environmental conditions in a subtidal prey refuge: effects of salinity stress, food availability and predation on mussels in a fjord system. Mar Ecol Prog Ser 422:201-210

Wing S, Leichter J, Perrin C, Rutger S, Bowman M, Cornelisen C (2007) Topographic shading and wave exposure influence morphology and ecophysiology of Ecklonia radiata (C. Agardh 1817) in Fiordland, New Zealand. Limnol Oceanogr 52:1853-1864

Wing S, McLeod R, Clark K, Frew R (2008) Plasticity in diet of two echinoderm species across an ecotone: microbial recycling of forest litter and bottom-up forcing of population structure. Mar Ecol Prog Ser 360:115-123

> Witman J, Grange K (1998) Links between rain, salinity, and predation in a rocky subtidal community. Ecology 79 : 2429-2447

Witman J, Leichter J, Genovese S, Brooks D (1993) Pulsed phytoplankton supply to the rocky subtidal zone: influence of internal waves. Proc Natl Acad Sci 90:1686-1690

Submitted: August 9, 2011; Accepted: January 6, 2012

Proofs received from author(s): April 19, 2012 